\title{
Molecular cloning, over expression and characterization of thermoalkalophilic esterases isolated from Geobacillus sp.
}

\author{
Hasan Cihad Tekedar • Gülşah Şanlı-Mohamed
}

Received: 27 July 2010/ Accepted: 1 December 2010/Published online: 23 December 2010

(C) Springer 2010

\begin{abstract}
Due to potential use for variety of biotechnological applications, genes encoding thermoalkalophilic esterase from three different Geobacillus strains isolated from thermal environmental samples in Balçova (Agamemnon) geothermal site were cloned and respective proteins were expressed in Escherichia coli (E.coli) and characterized in detail. Three esterases (Est1, Est2, Est3) were cloned directly by PCR amplification using consensus degenerate primers from genomic DNA of the strains Est1, Est 2 and Est 3 which were from mud, reinjection water and uncontrolled thermal leak, respectively. The genes contained an open reading frame (ORF) consisting of $741 \mathrm{bp}$ for Est1 and Est2, which encoded 246 amino acids and ORF of Est3 was 729 bp encoded 242 amino acids. The esterase genes were expressed in E. coli and purified using His-Select HF nickel affinity gel. The molecular mass of the recombinant enzyme for each esterase was approximately $27.5 \mathrm{kDa}$. The three esterases showed high specific activity toward short chain $p$-NP esters. Recombinant Est1, Est2, Est3 have exhibited similar activity and the highest esterase activity of $1,100 \mathrm{U} / \mathrm{mg}$ with $p$-nitrophenyl acetate $\left(p \mathrm{NPC}_{2}\right)$ as substrate was observed with Est1. All three esterase were most active around $65^{\circ} \mathrm{C}$ and $\mathrm{pH}$ 9.5-10.0. The effect of organic solvents, several metal ions, inhibitors and detergents on enzyme activity for purified Est1, Est2, Est3 were determined separately and compared.
\end{abstract}

Communicated by F. Robb.

H. C. Tekedar · G. Şanlı-Mohamed ( $\square)$

Department of Chemistry, Science Faculty,

İzmir Institute of Technology, Gülbahçe, Urla,

İzmir, Turkey

e-mail: gulsahsanli@iyte.edu.tr
Keywords Esterase - Geobacillus sp. - Thermophiles · Alkalophiles · Overexpression

\section{Introduction}

The majority of industrial enzymes produced by microorganisms are being utilized widely and their utilization on very diverse areas of industry is increasing rapidly (Miller and Nagarajan 2000). Esterases (EC 3.1.1.1), belong to the enzyme class of hydrolases, catalyze the hydrolytic cleavage and synthesis of carboxylic ester bonds. They are widely distributed in animals, plants and microorganisms (Bornscheuer 2002). These enzymes are of special interest in a variety of biotechnological applications because of their many useful properties such as broad range of natural and non-natural substrates, require no cofactor in the reactions, stability in organic solvents and exhibiting high regio and stereoselectivity (Faber 1997; Guagliardi et al. 1989; Jaeger et al. 1999). Every year novel biotechnological applications are established using esterases because of their important industrial and medical roles in the synthesis and hydrolysis of stereospecific compounds, including the metabolic processing of drugs and antimicrobial agents (Bornemann et al. 1992; Margolin 1993; Moher et al. 1989; Quax and Broekhuizen 1994). Due to the tremendous potential biotechnological use of these enzymes a search for enzymes with novel properties is being stimulated.

Enzymes from extremophiles can perform better in a number of commercial applications compared to other enzymes because of their surprising properties (Kristjansson 1989; Aguilar et al. 1998; Haki and Rakshit 2003; Maugeri et al. 2001; Owsu and Cowan 1989). Therefore, the isolation of extremophilic bacteria from natural sources and their identification are very important in terms of discovering new 
industrial enzymes. Unfortunately esterases are used less frequently in industrial processes compared to lipases mainly due to their lack of availability (Bornscheuer 2002; Faber 1997). Up to date, several thermostable lipases have been reported from thermophilic microorganisms (AbdelFattah and Gaballa 2006; Rua et al. 1997; Schmidt-Dannert et al. 1996; Kim et al. 1998; Margolin 1993), whereas only few thermostable esterases have been isolated from thermophile microorganisms in the literature (Ewis et al. 2004; Kademi et al. 1999; Mnisi et al. 2005).

The utilization of microorganisms from their sources is not suited for the production of enzymes in most cases; therefore, high level production of these biocatalysts can be achieved by cloning the genes encoding the enzymes of interest and overexpression in a heterologous system. Cloning of genes will also allow manipulation of enzymes at the genetic level for improved performance and novel characteristics.

In this paper, we have aimed to use micro-organisms that were previously isolated and characterized as a Geobacillus sp. from Balçova Geothermal region in Izmir, Turkey (Yavuz et al. 2004). Thermoalkaline stable esterases from those micro-organisms were isolated using recombinant DNA technology and were over expressed in E.coli. Furthermore they were characterized in terms of substrate specificity, optimum $\mathrm{pH}$ and temperature, stability and against organic solvents, some ions and denaturants.

\section{Materials and methods}

DNA preparation and cloning of the thermostable esterase genes

Three different isolates out of 112 bacterial strains from Balçova (Agamemnon) Geothermal Site in Izmir of Turkey, were selected for their high esterase activity by observing clear zones around the isolated colonies on Tween 20 agar plates after $24 \mathrm{~h}$ incubation at $55^{\circ} \mathrm{C}$. Est1, Est2, Est 3 were named according to bacterial sources from mud, reinjection water and uncontrolled thermal leak, respectively. Three strains served as sources for genomic DNA using a standard protocol of Genomic DNA purification Kit (Fermentas) according to manufacturer's recommendations.

A pair of degenerate primers was designed on the basis of the conserved region among esterases from G. stearothermophilus (GenBank: BAA02182.1), B. subtilis (GenBank: AAA19698.1) and G. thermoleovorans (GenBank: AAG53982.1) (Fig. 1). The primers used were EstF 5'-CAT ATG ATG AAA RTT GTT MCG CCG AAG-3' for forward and EstR $5^{\prime}$-AAG CTT TTA CCA ATC TAA CKW TTC AAG AAA- $3^{\prime}$ for reverse. The restriction sites $N d e \mathrm{I}$ and HindIII were incorporated into forward and reverse primer sequence, respectively. The ORF of the thermostable esterase genes was amplified from the genomic DNA of Est1, Est2, Est3 with Taq DNA polymerase with the following PCR conditions: an initial denaturation step at $94^{\circ} \mathrm{C}$ for $5 \mathrm{~min}$, followed by 30 cycles at $94^{\circ} \mathrm{C}$ for $1 \mathrm{~min}$, annealing at $58^{\circ} \mathrm{C}$ for $2 \mathrm{~min}$, and extension at $72^{\circ} \mathrm{C}$ for $2 \mathrm{~min}$, except for the final extension of $10 \mathrm{~min}$, and preservation at $4^{\circ} \mathrm{C}$. The amplified esterase genes were extracted from agarose gel by PCR purification kit (Fermentas) and purified DNA fragments were subcloned into TA cloning vector, pTZ57R/T according to the manufacturer's recommendations (Fermentas). The esterase genes were then restricted from the pTZ57R/T vector using NdeI and HindIII restriction endonucleases and purified using $1 \%$ agarose gel electrophoresis. The gel-extracted DNA fragments were ligated with $N d e \mathrm{I} / \mathrm{HindIII}$ restricted pET$28 \mathrm{a}(+)$ expression vector (Novagen). The nucleotide sequence of the genes in the pET-28a $(+)$ plasmid was determined. The nucleotide sequences of the Est1, Est2 and Est3 have been deposited in the EMBL Nucleotide Sequence Databases and assigned the accession numbers FN597621, FN597622 and FN597623, respectively.

Sequences retrieved from databases were analysed with FinchTV and CLUSTALW. Sequence homology analysis was done on the web server of the National Centre for Biotechnology Informations in the non-redundant nucleotide (nr-nt) or amino acid (nr-aa) databases using BLASTX, BLASTP and BLASTN programmes (Altschul et al. 1990).
G. stearothermophilus (GenBank: BAA02182.1) B. subtilis

(GenBank: AAA19698.1)

G. thermoleovorans

(GenBank: AAG53982.1)

Esterase

Fig. 1 Sequences alignment of reported thermostable esterases from Database with the designed primers of esterases using CLUSTALW Multiple Sequence Alignment Program. First eight and last eight codons of sequences are shown at $5^{\prime}$ and $3^{\prime}$ end, respectively. The middle of the sequences is shown by serial dots. Start and end codons

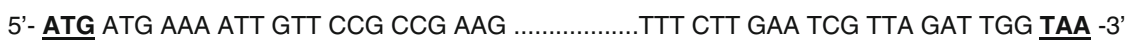

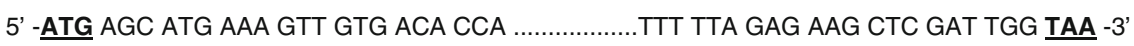

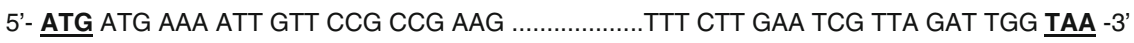

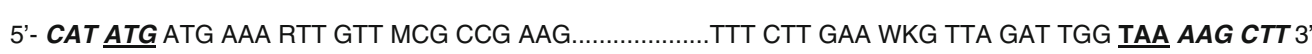

are underlined in each sequence. NdeI and HindIII restriction sites of degenerate primers of esterase are shaded. Letters other than G,C,T,A in the degenerate primers are described as following: $R$ (either $G$ or $\mathrm{A}), \mathrm{M}$ (either $\mathrm{C}$ or $\mathrm{A}), \mathrm{W}$ (either $\mathrm{T}$ or $\mathrm{A}), \mathrm{K}$ (either $\mathrm{T}$ or $\mathrm{G})$ 
Heterologous expression and purification of recombinant esterase genes in $E$. coli

Escherichia coli BL21(DE3) harboring the IPTG inducible plasmid pET-28a(+) encoding for thermophilic esterase enzymes were expressed and the purification of the enzymes was carried out using His-taq Nickel Affinity column followed by dialysis. Protein homogeneity was evaluated using Coomassie Blue visualized SDS PAGE (Laemmli 1970) and quantitative protein determination was performed by Bradford's method (Bradford 1976).

Assay of esterase activity

The esterase activity was assayed spectrophotometrically using $p \mathrm{NPC}_{2}$ as a substrate having one of the best hydrolytic activity among the variety of $p$-nitrophenyl ( $p$-NP) esters with different acyl chain lengths (C2-C16) in our studies. The assay mixture $(1 \mathrm{ml})$ contained $0.5 \mathrm{mM}$ $p \mathrm{NPC}_{2} \quad$ substrate dissolved in acetonitrile including Reagent A buffer [100 mM sodium phosphate buffer with $150 \mathrm{mM}$ sodium chloride and $0.5 \%$ (v/v) Triton X-100, $\mathrm{pH}$ 7.2]. $0.1 \mathrm{mg} / \mathrm{ml}$ purified enzyme was used and initial rates were estimated by measuring the increase in absorbance at $400 \mathrm{~nm}$ as a function of time at $55^{\circ} \mathrm{C}$. One unit of esterase activity was defined as the amount of enzyme releasing $1.0 \mu \mathrm{mol}$ of $p$-nitrophenol per minute at $\mathrm{pH} 7.2$ at $55^{\circ} \mathrm{C}$ using $p \mathrm{NPC}_{2}$ as a substrate.

\section{Determination of substrate specificity}

Enzyme activity of purified esterase enzymes toward $p$-NP esters of various chain lengths was performed spectrophotometrically at $55^{\circ} \mathrm{C}$ to determine substrate preference. The following compounds were used as substrates at a concentration of $50 \mathrm{mM}$; $p$-NP acetate (C2), $p$-NP butyrate (C4), $p$-NP caproate (C6), $p$-NP caprylate (C8), $p$-NP caprate (C10), $p$-NP laurate (C12), $p$-NP myristate (C14) and $p$-NP palmitate (C16).

Effect of $\mathrm{pH}$ and temperature on enzyme activity

The effect of $\mathrm{pH}$ on enzyme activity was investigated using buffers at different $\mathrm{pH}$ ranging from 4 to 12 . Three different buffers having $50 \mathrm{mM}$ ionic strength were used to cover the $\mathrm{pH}$ range, which were acetate buffer $(\mathrm{pH} 4-5.5)$, sodium phosphate buffer ( $\mathrm{pH}$ 6-8), and glycine- $\mathrm{NaOH}$ buffer ( $\mathrm{pH} 8.5-12)$. The optimum $\mathrm{pH}$ of the enzyme was determined under the standard assay conditions by measuring activity in the presence of the indicated buffers.

The effect of temperature on esterase enzyme activity was examined under standard assay conditions at different temperatures $\left(30,40,50,55,60,65,70,75,80\right.$ and $\left.90^{\circ} \mathrm{C}\right)$ and the buffer was heated to the relevant temperature before the assay.

Temperature stability on enzyme activity was assayed by incubating the enzyme solution at $45,55,65$ and $75^{\circ} \mathrm{C}$ for $6 \mathrm{~h}$ and then measuring the remaining activity using standard enzyme assay procedure.

Effect of organic solvents, inhibitors, metal ions and various agents on esterase activity

Est1, Est2, Est3 enzyme was incubated separately in the presence of $1 \%$ of various organic solvents (isopropanol, ethanol, methanol, acetone, hexane, chloroform) or $1 \mathrm{mM}$ of a variety of metal ions $\left(\mathrm{MgCl}_{2}, \mathrm{CaCl}_{2}, \mathrm{CuCl}_{2}, \mathrm{MnCl}_{2}\right.$, $\mathrm{LiCl}, \mathrm{KCl}, \mathrm{FeCl}_{3}, \mathrm{NaCl}, \mathrm{ZnCl}_{2}$ ) or $1 \% / 1 \mathrm{mM}$ of various agents (DMSO, DTT, SDS, EDTA, $\beta$-Mercaptoethanol, PMSF, Chaps, TritonX-100, Tween 20) at room temperature for $15 \mathrm{~min}$. The reaction was initiated by addition of $p \mathrm{NPC}_{2}$ and change in absorbance was measured under standard enzyme assay conditions.

\section{Kinetic studies}

Kinetic parameters of Est1, Est2, Est3 were determined using Lineweaver-Burk plots assuming that the reactions followed a simple Michaelis-Menten kinetics. LineweaverBurk curves were obtained for $p \mathrm{NPC}_{2}$ at six different substrate concentration $(0.05,0.1,0.3,0.5,0.7$ and $1 \mathrm{mM})$ using standard enzyme assay.

\section{Results and discussion}

Cloning and sequence analysis of esterase genes from Geobacillus sp

Based on the screening for thermophiles with esterase activity, bacterial isolates Est1, Est 2 and Est 3 showing the highest esterase production were obtained from Balçova (Agamemnon) Geothermal Site in Izmir of Turkey (Yavuz et al. 2004). The strains Est1, Est2 and Est3 were from mud, reinjection water and uncontrolled thermal leak, respectively. With the genomic DNA of Est1, Est2 and Est3, a 744-bp fragment for Est1 and Est2 and a 729-bp fragment for Est3 were obtained by PCR. Each gene was individually subcloned into pTZ57R/T vector facilitated by single $3^{\prime}-\mathrm{T}$ overhang of the vector and a single $3^{\prime}-\mathrm{A}$ overhang of the PCR product conferred by Taq DNA polymerase. The fragments contained an ORF encoding 246 amino acids for Est1 and Est2 and 242 amino acids for Est3. The nucleotide sequences of Est1, Est2, Est3 shares $99 \%$ identities with each other. Only a total of six positions (\# of nucleotide: 10, 16, 238,328, 549, 731) 
were different in the nucleotide sequences that have resulted in a total four amino acid differences (\#of amino acid: 4, 6, 110, 244) among the three esterase genes (Fig. 2). In terms of amino acid sequence alignment, Est1 has displayed $97 \%$ homology with Est2 and Est3 and Est2 has showed $99 \%$ sequence identity with Est3. The deduced amino acid sequences were subjected to BLAST in GenBank. The results showed that they were highly homologous to known esterases. Therefore, these ORFs were suggested to be the esterase gene of Geobacillus sp. The sequences were identified also due to the sequence motif GXSXG which is typical to $\alpha / \beta$-hydrolases such as lipases and esterases (Ollis et al. 1992). In addition to the GXSXG motif, the esterases contain the highly conserved GX-motif of the oxyanion hole architecture and thus could be assigned to the GX class (Pleiss et al. 2000). The amino acid sequence of Est1, Est2 and Est3 esterases shares 96-98, 97-99, 95-98, and 73-74\% identities with esterases from G. stearothermophilus, G. kaustophilus HTA426, G. thermoleovorans, and B. subtilis subsp. subtilis str. 168, respectively (Ewis et al. 2004; MontoroGarcía et al. 2009; Soliman et al. 2007, Kneusel et al. 1994).

Expression and purification of recombinant esterase proteins

Est1, Est2 and Est3 genes were expressed in E. coli upon derepression of the lac operator by the lactose analog IPTG. The IPTG induced bacteria was compared to noninduced control bacterium by SDS-PAGE. The bands (about $27.5 \mathrm{kDa}$ ) corresponding to the esterase proteins for Est1, Est2 and Est3 were observed in the induced recombinant bacterium containing esterase genes and no protein expression was found in the same positions in non-induced controls. These showed that the esterase genes were expressed successfully.

Three enzymes were efficiently purified to homogeneity, resulted in a single protein band for each enzyme using the Ni-NTA-based purification method taking advantage of the attached His-tag. SDS-PAGE analysis indicated that the proteins were homogenous, and further analysis on SDS gels indicated a molecular mass of approximately $27.5 \mathrm{kDa}$ for Est1, Est2 and Est3 proteins.

The result of heterologous expression and purification of each esterase has indicated that approximately 20-30 mg of purified active protein can be isolated from 1.01 of bacterial culture in LB media. The purified enzymes showed high specific activities: 800-1,100 $\mathrm{U} / \mathrm{mg}$ for Est1, Est2 and Est3. The purified enzymes were stable not only in solution stored at $4{ }^{\circ} \mathrm{C}$ but also the lyophilized form without any loss of activity over several months.
Biochemical characterizations of recombinant esterase proteins

Activity measurement of each enzyme was performed using a variety of $p$-nitrophenyl esters with different chain length. The selection of the substrates was intended to cover broad chain lengths of esters (C2-C16) thus providing a most complete picture of the enzymes' substrate preferences. The results (Fig. 3) show that the highest activity of esterase was obtained toward $p \mathrm{NPC}_{2}$ for Est1, Est2, Est3. When the acyl chain length of the substrate was increased starting with $\mathrm{C} 2$, there was a gradual decrease in the enzyme activity. All three esterases have shown similar response toward substrates with different relative activity (Fig. 3). Similar results have been demonstrated by other studies (Soliman et al. 2007; Yildirim et al. 2009; MontoroGarcía et al. 2009) having the highest esterase activity toward $p$-nitrophenyl acetate. The results were not surprising because esterase use short chain fatty acids as substrate for their catalytic activity. Uncommonly some activity toward PNP-palmitate (C16 acyl group) was detected. The same was found in case of an esterase from a newly isolated moderate thermophilic bacterium (Kademi et al. 1999) and another esterases from G. thermoleovorans $Y N$ and G. kaustophilus HTA426 (Montoro-García et al. 2009; Soliman et al. 2007) having the highest activity with PNP-acetate (C2) and very little activity with PNPpalmitate $(\mathrm{C} 16)$.

Est1, Est2 and Est3 have resulted in a similar way in catalytic reactions measuring the kinetic constants of the enzymes with $p \mathrm{NPC}_{2}$ as the substrate. The esterases exhibited a simple Michaelis-Menten kinetics and Lineweaver-Burk plot showed a linear response over the tested concentration range. The $K_{\mathrm{m}}$ and $k_{\text {cat }}$ values of Est 1 were estimated to be $0.095 \mathrm{mM}$ and $19,758 \mathrm{~s}^{-1}$, while $K_{\mathrm{m}}$ of Est 2 and Est 3 were $0.24 \mathrm{mM}$ and $0.17 \mathrm{mM}$, respectively and $k_{\text {cat }}$ values of Est 2 and Est 3 were $14,135 \mathrm{~s}^{-1}$ and $17,666 \mathrm{~s}^{-1}$ respectively.

The results of Est1, Est 2 and Est 3 activities as a function of temperature have showed that all three esterase hydrolyzed $p \mathrm{NPC}_{2}$ in a broad temperature range of $30-80^{\circ} \mathrm{C}$, with the maximal activity at $65^{\circ} \mathrm{C}$ (Fig. 4a). Similar results were also reported for esterases from $G$. thermoleovorans $Y N$, G. stearothermophilus and G. caldoxylosilyticus TK4 (Soliman et al. 2007; Yildirim et al. 2009; Ewis et al. 2004). Although the enzymes have exhibited similar activity trend with increased temperature, their activities were slightly different at lower and higher temperature. Est 1 has $45 \%$ relative activity at $30^{\circ} \mathrm{C}$ but Est 3 has quite lower activity $(25 \%)$ at the same temperature compared to Est1. All three recombinant enzymes were shown to be no longer active at $90^{\circ} \mathrm{C}$. While Est3 has exhibited $40 \%$ relative activity at $80^{\circ} \mathrm{C}$, Est 1 has lost most of its activity at 
Fig. 2 CLUSTAL 2.0.11

multiple sequence alignment of Est1, Est2, Est3 genes with their deduced amino acid sequence.

The identical nucleotides in the sequences were indicated with asterisks. The amino acids in parenthesis represent amino acid differences among Est1, Est 2 and Est 3 . The location of forward and reverse primers was underlined. The position of the GXSXG and GX sequences was dashed and dotted underlined, respectively. (....) shows no nucleotides in the sequence
ATGATGAAAATTGTTCCGCCGAAGCCGTTTTTCTTTGAAGCCGGGGAGCGGGCGGTGCTG 60 ATGATGAAAGTTGTTCCGCCGAAGCCGTTTTTCTTTGAAGCCGGGGAGCGGGCGGTGCTG 60 ATGATGAAAGTTGTTACGCCGAAGCCGTTTTTCTTTGAAGCCGGGGAGCGGGCGGTGCTG 60

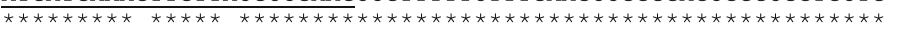
$\begin{array}{lllllllllllllllllllll}M & M & K & I & V & P & P & K & P & F & F & F & E & A & G & E & R & A & V & L & 20\end{array}$ (V) $\quad(\mathrm{T})$

CTTTTGCATGGGTTTACCGGCAATTCCGCCGACGTTCGGATGCTTGGGCGATTCTTGGAA 120 CTTTTGCATGGGTTTACCGGCAATTCCGCCGACGTTCGGATGCTTGGGCGATTCTTGGAA 120 CTTTTGCATGGGTTTACCGGCAATTCCGCCGACGTTCGGATGCTTGGGCGATTCTTGGAA 120

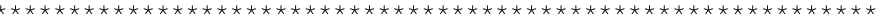
$\begin{array}{llllllllllllllllllllll}L & L & H & G & F & T & G & N & S & A & D & V & R & M & L & G & R & F & L & E & 40\end{array}$

TCGAAAGGGTATACGTGCCACGCTCCGATTTACAAAGGGCATGGCGTGCCGCCGGAAGAG 180 TCGAAAGGGTATACGTGCCACGCTCCGATTTACAAAGGGCATGGCGTGCCGCCGGAAGAG 180 TCGAAAGGGTATACGTGCCACGCTCCGATTTACAAAGGGCATGGCGTGCCGCCGGAAGAG 180

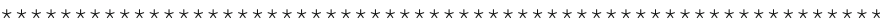

$\begin{array}{llllllllllllllllllllll}\mathrm{S} & K & G & Y & \mathrm{~T} & \mathrm{C} & \mathrm{H} & \mathrm{A} & \mathrm{P} & \mathrm{I} & \mathrm{Y} & \mathrm{K} & \mathrm{G} & \mathrm{H} & \mathrm{G} & \mathrm{V} & \mathrm{P} & \mathrm{P} & \mathrm{E} & \mathrm{E} & 60\end{array}$

CTCGTCCACACCGGACCGGATGATTGGTGGCAAGACGTCATGAACGGCTATCAGTTTTTG 240 CTCGTCCACACCGGACCGGATGATTGGTGGCAAGACGTCATGAACGGCTATCAGTTTTTG 240 CTCGTCCACACCGGACCGGATGATTGGTGGCAAGACGTCATGAACGGCTATCAGTTTCTG 240

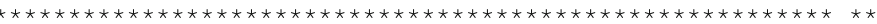

$\begin{array}{llllllllllllllllllllll}\mathrm{L} & \mathrm{V} & \mathrm{H} & \mathrm{T} & \mathrm{G} & \mathrm{P} & \mathrm{D} & \mathrm{D} & \mathrm{W} & \mathrm{W} & \mathrm{Q} & \mathrm{D} & \mathrm{V} & \mathrm{M} & \mathrm{N} & \mathrm{G} & \mathrm{Y} & \mathrm{Q} & \mathrm{F} & \mathrm{L} & 80\end{array}$

AAAAACAAAGGCTACGAAAAAATTGCCGTGGCTGGATTGTCGCTTGGAGGCGTATTTTCT 300 AAAAACAAAGGCTACGAAAAAATTGCCGTGGCTGGATTGTCGCTTGGAGGCGTATTTTCT 300 AAAAACAAAGGCTACGAAAAAATTGCCGTGGCTGGATTGTCGCTTGGAGGCGTATTTTCT 300

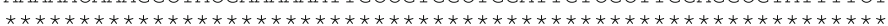

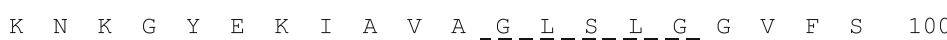

CTCAAATTAGGCTACACTGTACCTATAGAAGGCATTGTGACGATGTGCGCGCCGATGTAC 360 CTCAAATTAGGCTACACTGTACCTATACAAGGCATTGTGACGATGTGCGCGCCGATGTAC 360 CTCAAATTAGGCTACACTGTACCTATAGAAGGCATTGTGACGATGTGCGCGCCGATGTAC 360

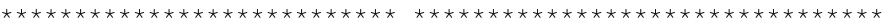

$\begin{array}{lllllllllllllllllllllll}\mathrm{L} & \mathrm{K} & \mathrm{L} & \mathrm{G} & \mathrm{Y} & \mathrm{T} & \mathrm{V} & \mathrm{P} & \mathrm{I} & \mathrm{E} & \mathrm{G} & \mathrm{I} & \mathrm{V} & \mathrm{T} & \mathrm{M} & \mathrm{C} & \mathrm{A} & \mathrm{P} & \mathrm{M} & \mathrm{Y} & 120\end{array}$ (Q)

ATCAAAAGCGAAGAAACGATGTACGAAGGTGTGCTCGAGTATGCGCGCGAGTATAAAAAG 420 ATCAAAAGCGAAGAAACGATGTACGAAGGTGTGCTCGAGTATGCGCGCGAGTATAAAAAG 420 ATCAAAAGCGAAGAAACGATGTACGAAGGTGTGCTCGAGTATGCGCGCGAGTATAAAAAG 420

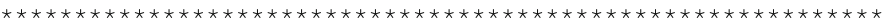

$\begin{array}{lllllllllllllllllllll}I & K & S & E & E & T & M & Y & E & G & V & L & E & Y & A & R & E & Y & K & K & 140\end{array}$

CGGGAAGGGAAATCAGAGGAACAAATCGAACAGGAAATGGAACGGTTCAAACAAACGCCG 480 CGGGAAGGGAAATCAGAGGAACAAATCGAACAGGAAATGGAACGGTTCAAACAAACGCCG 480 CGGGAAGGGAAATCAGAGGAACAAATCGAACAGGAAATGGAACGGTTCAAACAAACGCCG 480

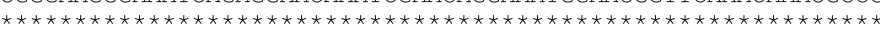

$\begin{array}{lllllllllllllllllllll}R & E & G & K & S & E & E & Q & I & E & Q & E & M & E & R & F & K & Q & T & P & 160\end{array}$

ATGAAGACGTTGAAAGCCTTGCAAGAACTCATTGCCGATGTGCGCGCCCACCTTGATTTG 540 ATGAAGACGTTGAAAGCCTTGCAAGAACTCATTGCCGATGTGCGCGCCCACCTTGATTTG 540 ATGAAGACGTTGAAAGCCTTGCAAGAACTCATTGCCGATGTGCGCGCCCACCTTGATTTG 540

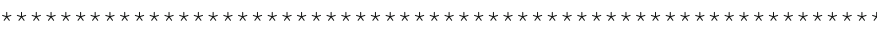

$\begin{array}{lllllllllllllllllllll}M & K & \mathrm{~T} & \mathrm{~L} & \mathrm{~K} & \mathrm{~A} & \mathrm{~L} & \mathrm{Q} & \mathrm{E} & \mathrm{L} & \mathrm{I} & \mathrm{A} & \mathrm{D} & \mathrm{V} & \mathrm{R} & \mathrm{A} & \mathrm{H} & \mathrm{L} & \mathrm{D} & \mathrm{L} & 180\end{array}$

GTTTATGCGCCGACGTTCGTCGTCCAAGCGCGCCATGATGAGATGATCAATCCAGACAGC 600 GTTTATGCACCGACGTTCGTCGTCCAAGCGCGCCATGATGAGATGATCAATCCAGACAGC 600 GTTTATGCGCCGACGTTCGTCGTCCAAGCGCGCCATGATGAGATGATCAATCCAGACAGC 600

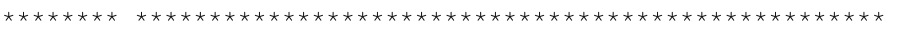

$\begin{array}{lllllllllllllllllllll}\mathrm{V} & \mathrm{Y} & \mathrm{A} & \mathrm{P} & \mathrm{T} & \mathrm{F} & \mathrm{V} & \mathrm{V} & \mathrm{Q} & \mathrm{A} & \mathrm{R} & \mathrm{H} & \mathrm{D} & \mathrm{E} & \mathrm{M} & \mathrm{I} & \mathrm{N} & \mathrm{P} & \mathrm{D} & \mathrm{S} & 200\end{array}$

GCGAACATCATTTATAACGAAATTGAATCGCCGGTCAAACAAATCAAATGGTATGAGCAA 660 GCGAACATCATTTATAACGAAATTGAATCGCCGGTCAAACAAATCAAATGGTATGAGCAA 660 GCGAACATCATTTATAACGAAATTGAATCGCCGGTCAAACAAATCAAATGGTATGAGCAA 660

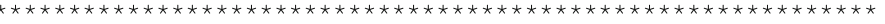

$\begin{array}{lllllllllllllllllllll}A & N & I & I & Y & N & E & I & E & S & P & V & K & Q & I & K & W & Y & E & Q & 220\end{array}$

TCAGGCCATGTGATTACGCTTGATCAAGAAAAAGATCAGCTGCATGAAGATATTTATGCA 720 TCAGGCCATGTGATTACGCTTGATCAAGAAAAAGATCAGCTGCATGAAGATATTTATGCA 720 TCAGGCCATGTGATTACGCTTGATCAAGAAAAAGATCAGCTGCATGAAGATATTTATGCA 720

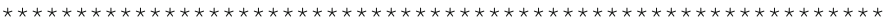

$\begin{array}{lllllllllllllllllllll}S & G & H & V & I & T & L & D & Q & E & K & D & Q & L & H & E & D & I & Y & A & 240\end{array}$

TTTCTTGAATCGTTAGATTGGTAA 744 TTTCTTGAATCGTTAGATTGGTAA 744

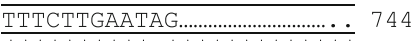

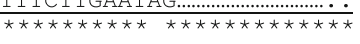

F $\quad L \quad E \quad S \quad L \quad D \quad W \quad 247$

$(-)$ 


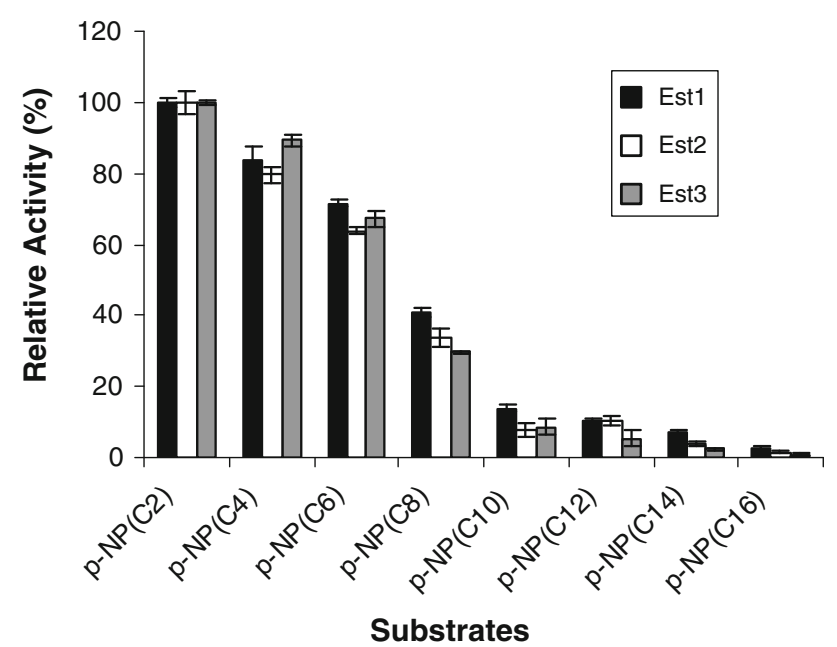

Fig. 3 Substrate specificity of the purified Est1, Est2, Est3 toward $p$-nitrophenyl esters of various chain lengths. Enzyme activity was performed spectrophotometrically at $55^{\circ} \mathrm{C}$ and $\mathrm{pH} 7.2$. The results were expressed as relative activities (\%)

the same temperature showing $<10 \%$ relative enzyme activity.

The esterase activity of Est1, Est2 and Est3 was measured at various $\mathrm{pHs}$ in buffers with the same ionic concentrations. All three esterase hydrolyzed $p \mathrm{NPC}_{2}$ in a broad $\mathrm{pH}$ range of 7.0-12.0 having the maximum esterase activity at $\mathrm{pH} 9.5$ for Est1 and Est3 and $\mathrm{pH} 10.0$ for Est2 (Fig. 4b). Their activities were, however, very low at $\mathrm{pHs}$ below 7.0 with no activity below $\mathrm{pH}$. The recombinant esterases were very stable when held at $\mathrm{pH} 9.5-11.0$ for hours, retaining $80-100 \%$ of its initial activity (data is not shown) indicating that the recombinant enzymes are extremely alkali-tolerant proteins. Similar to the results here, esterase enzyme from $G$. thermoleovorans and $B$. subtilis have been reported to be more active and stable at alkaline pH (Eggert et al. 2000; Soliman et al. 2007). This is in fact a desirable property for industrial applications.

Thermal stability of esterase enzymes was tested at various temperatures $\left(45,55,65,75^{\circ} \mathrm{C}\right)$. Since three esterase enzymes displayed similar overall activity patterns in terms of thermostability, only the results of Est1 has been shown in Fig. 5. The enzymes remained relatively stable at $45^{\circ} \mathrm{C}$ and could be incubated for at least $6 \mathrm{~h}$ without a major loss of activity at this temperature. All three enzymes have retained more than $90 \%$ activity after incubation for $1 \mathrm{~h}$ at 55 and $65^{\circ} \mathrm{C}$. However, incubation at temperatures above $75^{\circ} \mathrm{C}$ for more than 60 min resulted in a rapid inactivation of enzymes and lost almost all activities after $3 \mathrm{~h}$. High thermostability has been shown with other homologous enzymes from $G$. thermoleovorans, G. stearothermophilus, Geobacillus sp. and G. kaustophilus HTA426 (Soliman et al. 2007; Owsu and Cowan 1991; Janssen et al. 1994; Montoro-García et al. 2009).
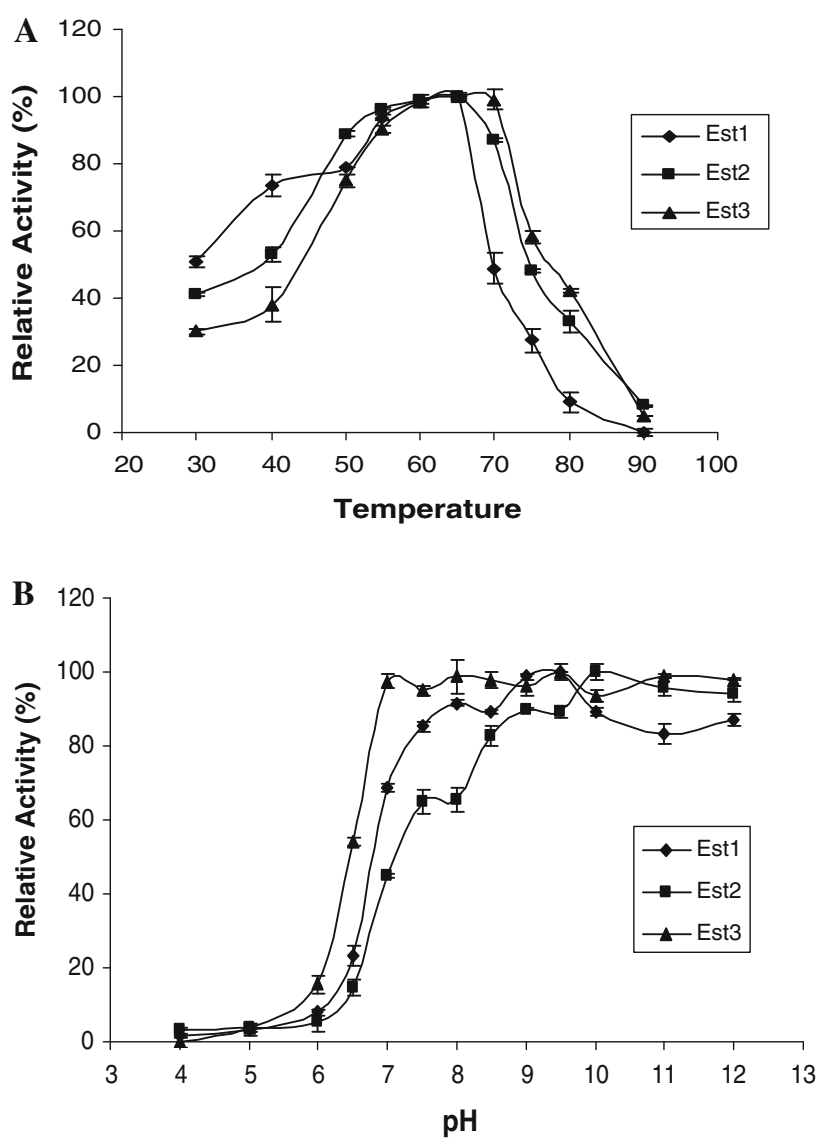

Fig. 4 a Effect of temperature on the activity of the purified esterases. Enzyme activity was examined under standard assay conditions at different temperatures $(30,40,50,55,60,65,70,75$, 80 and $\left.90^{\circ} \mathrm{C}\right)$. The results were expressed as relative activities $(\%)$. b Effect of the $\mathrm{pH}$ on the activity of the purified esterases. Enzyme activity was determined in the presence of buffers at different $\mathrm{pH}$ values ranging from 4.0 to 12.0 by $0.5 / 1.0$ increments. The results were expressed as relative activities (\%)

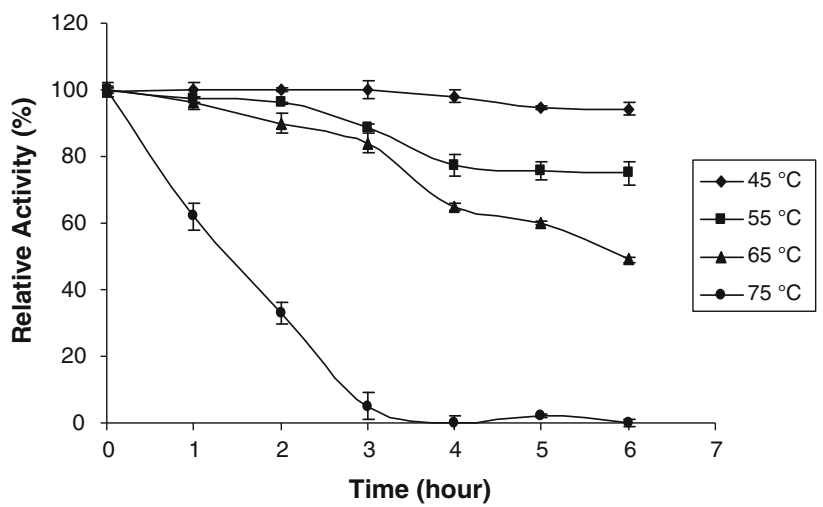

Fig. 5 Temperature stability of Est1, Est2, Est3 was assayed individually by incubating each enzyme solution at 45, 55, 65 and $75^{\circ} \mathrm{C}$ for $6 \mathrm{~h}$ and the measuring the remaining activity using standard enzyme assay procedure. The results were expressed as relative activities $(\%)$ 
Table 1 Effect of several organic solvents on Est1, Est2, Est3 enzyme activities

\begin{tabular}{lrrr}
\hline Organic solvents & \multicolumn{1}{l}{ Est1 } & \multicolumn{1}{l}{ Est2 } & \multicolumn{1}{l}{ Est3 } \\
\hline None & $100 \pm 0.0$ & $100 \pm 0.0$ & $100 \pm 0.0$ \\
Isopropanol & $41 \pm 1.3$ & $72 \pm 7.1$ & $69 \pm 2.2$ \\
Ethanol & $89 \pm 2.1$ & $95 \pm 2.5$ & $87 \pm 0.7$ \\
Methanol & $97 \pm 1.0$ & $93 \pm 1.3$ & $98 \pm 1.3$ \\
Acetone & $88 \pm 0.6$ & $79 \pm 6.9$ & $77 \pm 5.8$ \\
Hexane & $67 \pm 3.1$ & $50 \pm 0.5$ & $55 \pm 7.5$ \\
Chloroform & $25 \pm 0.9$ & $10 \pm 4.9$ & $19 \pm 9.1$ \\
\hline
\end{tabular}

Enzyme activities were assayed spectrophotometrically using PNPacetate as substrate upon incubation of the enzyme $(15 \mathrm{~min})$ in each solvent; the applied reaction conditions were $\mathrm{pH} 7.2$ and $55^{\circ} \mathrm{C}$. The results were expressed as relative activities (\%)

As shown in Tables 1, 2, and 3, the recombinant esterases were highly active when organic solvents, various metal ions and enzyme inhibitors/detergents were used, showing the properties of thermostable enzymes. Stability or enhancement of enzyme activity against organic solvents is very important when using enzymes for synthesis of esters and generally considered as a valid feature, as it is a prerequisite for the synthesis of chiral compounds in nonaqueous solvents (Zaks and Klibanov 1998). Influence of several organic solvents on Est1, Est2 and Est3 activities is represented on Table 1. The strongest inhibition effect on each enzyme was observed with chloroform (75-90\% activity lost). Isopropanol also inhibited the activity of purified Est1, Est2 and Est3 and the strongest inhibition was observed with Est1, losing $60 \%$ of total activity. Although Est1, Est2 and Est3 were less influenced in the presence of acetone (10-20\% activity lost), almost 90\% activity loss was observed with esterase from Geobacillus sp. $H B B-4$ in presence of $50 \%$ acetone (Kubilay et al. 2006). Activities of all three enzymes were also influenced with hexane leaving 50-70\% active enzymes after $10 \mathrm{~min}$ incubation at $55^{\circ} \mathrm{C}$. No effect or very little effect on the Est1, Est2 and Est 3 activity was observed in presence of methanol and ethanol. However, recombinant esterase enzyme of $G$. thermoleovorans $Y N$ showed stability toward ethanol (Soliman et al. 2007). The activity of carboxylesterase from G. kaustophilus HTA426 was not significantly affected at low concentrations of organic solvents but strongly inactivated at higher concentrations (MontoroGarcía et al. 2009). Similarly increase in solvent concentration up to $10 \%$ has resulted in a concentration dependent decrease of enzyme activity (data is not shown) in standard assay conditions. Also, the stability of esterase activity in presence of organic solvents was enhanced up to $15-20 \%$ by lowering the temperature to $45^{\circ} \mathrm{C}$ (data is not shown).

The purified Est1, Est2 and Est3 were incubated with different reagents as inhibitors at a final concentration of
Table 2 Effect of various enzyme inhibitors on Est1, Est2, Est3 enzyme activities

\begin{tabular}{llll}
\hline Inhibitors & \multicolumn{1}{l}{ Est1 } & \multicolumn{1}{l}{ Est2 } & Est3 \\
\hline None & $100 \pm 0.0$ & $100 \pm 0.0$ & $100 \pm 0.0$ \\
DMSO & $101 \pm 4.7$ & $113 \pm 4.1$ & $110 \pm 1.6$ \\
DTT & $111 \pm 4.5$ & $112 \pm 4.9$ & $109 \pm 5.8$ \\
EDTA & $122 \pm 2.8$ & $116 \pm 5.7$ & $124 \pm 2.4$ \\
2ME & $112 \pm 0.6$ & $106 \pm 2.4$ & $101 \pm 1.9$ \\
PMSF & $45 \pm 1.2$ & $58 \pm 1.9$ & $55 \pm 1.4$ \\
Chaps & $88 \pm 1.1$ & $92 \pm 1.4$ & $90 \pm 0.8$ \\
SDS & $81 \pm 2.3$ & $57 \pm 3.2$ & $50 \pm 3.2$ \\
TritonX-100 & $97 \pm 3.2$ & $95 \pm 2.8$ & $98 \pm 2.8$ \\
Tween 20 & $78 \pm 1.7$ & $87 \pm 2.3$ & $69 \pm 0.3$ \\
\hline
\end{tabular}

Enzyme activities were assayed spectrophotometrically using PNPacetate as substrate upon incubation of the enzyme $(15 \mathrm{~min})$ in each inhibitor; the applied reaction conditions were $\mathrm{pH} 7.2$ and $55^{\circ} \mathrm{C}$. The results were expressed as relative activities (\%)

Table 3 Effect of various metal ions on Est1, Est2, Est3 enzyme activities

\begin{tabular}{lrrr}
\hline Ions & \multicolumn{1}{c}{ Est1 } & \multicolumn{1}{c}{ Est2 } & \multicolumn{1}{c}{ Est3 } \\
\hline None & $100 \pm 0.0$ & $100 \pm 0.0$ & $100 \pm 0.0$ \\
$\mathrm{CaCl}_{2}$ & $110 \pm 1.9$ & $121 \pm 6.1$ & $103 \pm 2.6$ \\
$\mathrm{CuCl}_{2}$ & $88 \pm 2.9$ & $81 \pm 2.9$ & $83 \pm 0.9$ \\
$\mathrm{MgCl}_{2}$ & $92 \pm 0.4$ & $95 \pm 4.6$ & $97 \pm 1.0$ \\
$\mathrm{MnCl}_{2}$ & $98 \pm 4.1$ & $96 \pm 1.1$ & $96 \pm 2.9$ \\
$\mathrm{ZnCl}_{2}$ & $111 \pm 1.1$ & $104 \pm 2.0$ & $115 \pm 3.3$ \\
$\mathrm{LiCl}$ & $89 \pm 0.9$ & $95 \pm 2.1$ & $93 \pm 1.7$ \\
$\mathrm{KCl}$ & $101 \pm 2.1$ & $98 \pm 3.1$ & $99 \pm 1.1$ \\
$\mathrm{NaCl}$ & $123 \pm 2.6$ & $112 \pm 2.5$ & $108 \pm 1.3$ \\
$\mathrm{FeCl}$ & $98 \pm 2.2$ & $98 \pm 0.3$ & $99 \pm 0.2$ \\
\hline
\end{tabular}

Enzyme activities were assayed spectrophotometrically using PNPacetate as substrate upon incubation of the enzyme $(15 \mathrm{~min})$ in each compound; the applied reaction conditions were $\mathrm{pH} 7.2$ and $55^{\circ} \mathrm{C}$. The results were expressed as relative activities (\%)

$1 \mathrm{mM}$ or $1 \%$ for $10 \mathrm{~min}$ at $55^{\circ} \mathrm{C}$ (Table 2). All three esterase enzymes were affected in a similar way by denaturing agents. Among the inhibitors analyzed, PMSF, which is typical for serine hydrolases, was the most effective inhibitor of Est1, Est2, and Est3. Almost 50\% of esterase activity was observed in presence of $1 \mathrm{mM}$ PMSF. $5 \mathrm{mM}$ PMSF completely deactivated Est1, Est2 and Est3 (data is not shown). No enzyme activity of carboxylesterase from G. kaustophilus HTA426 was observed in presence of PMSF (Montoro-García et al. 2009). The enzymes were also rapidly inhibited by SDS at a concentration of $1 \mathrm{mM}$. SDS also showed very strong inhibitory effect on the esterase from $G$. thermoleovorans, 
Geobacillus sp. HBB-4 and G. kaustophilus HTA426 (Soliman et al. 2007; Kubilay et al. 2006; Montoro-García et al. 2009). The inhibition with PMSF and SDS was essentially irreversible as judged by the activity assay of the enzyme after exhaustive dialysis. The activity of Est1, Est2 and Est3 was slightly inhibited from 10 to $30 \%$ with CHAPS, TritonX-100 and Tween 20. Similar results were obtained with esterase from Geobacillus sp. HBB-4 and G. kaustophilus HTA426 (Kubilay et al. 2006; MontoroGarcía et al. 2009). Contrary to other inhibitors, DMSO, DTT and 2-mercaptoethanol enhanced the activity of the three esterases with varying degree. Similar to our results here, the esterase from $G$. thermoleovorans and Geobacillus sp. $H B B-4$ was also activated by the same reducing agents (Soliman et al. 2007; Kubilay et al. 2006). The highest increase in activity of the enzymes $(\sim 25 \%)$ was determined in presence of $1 \mathrm{mM}$ EDTA. Contradictory, a slight inhibiting effect was shown by EDTA on the activity of esterase from $G$. thermoleovorans $Y N$ and stronger inhibitory effect was observed on esterase from Geobacillus sp. HBB-4 (Soliman et al. 2007; Kubilay et al. 2006).

The effects of metal ions on the recombinant enzymes were evaluated as shown in Table 3. Est1, Est2 and Est3 enzymes displayed similar overall activity patterns with a small variation as a result of metal ion treatments. In the presence of $\mathrm{CaCl}_{2}(1 \mathrm{mM}), \mathrm{ZnCl}_{2}(1 \mathrm{mM})$ and $\mathrm{NaCl}$ $(1 \mathrm{mM})$, the activities of recombinant esterases were enhanced using the standard assay with $p \mathrm{NPC}_{2}$ as substrate. In contrast to our results, esterase from $G$. thermoleovorans YN and G. caldoxylosilyticus TK4 was strongly inhibited in the presence of $\mathrm{Zn}^{2+}$ (Yildirim et al. 2009; Soliman et al. 2007). The most effective increase of esterase activity $(\sim 25 \%)$ was observed in the presence of $\mathrm{NaCl}$. The esterases activities were slightly decreased by $\mathrm{LiCl}$ and $\mathrm{CuCl}_{2}$. However, no esterase activity was changed in the presence of other metal ions $\left(\mathrm{MgCl}_{2}, \mathrm{MnCl}_{2}, \mathrm{KCl}, \mathrm{FeCl}_{3}\right)$.

\section{Conclusion}

The three esterase enzymes described in this study from Balçova Geothermal Region represent an example for the high potential of microbial inhabitants of geothermal regions. Balçova Geothermal Region was a source for new thermophilic microorganisms and enzymes with novel industrially important properties. Although all three enzymes share some properties with other enzymes, all of them are very stable in high temperatures up to $70^{\circ} \mathrm{C}$ and surprisingly also at high $\mathrm{pH}$ values. Due to this and other unusual properties of the enzymes such as their high resistance against a variety of substances, the enzymes are valuable candidates for industrial applications.
Acknowledgments The authors would like to thank TUBITAK (The scientific and Technological Research Council of Turkey) and Izmir Institute of Technology-Research Foundation for financial support. The authors also would like to thank Biotechnology \& Bioengineering Research Center at İzmir Institute of Technology for the facilities and technical support.

\section{References}

Abdel-Fattah YR, Gaballa AA (2006) Identification and overexpression of a thermostable lipase from Geobacillus thermoleovorans Toshki in Escherichia coli. Microbiol Res 163:13-20

Aguilar A, Ingemansson T, Magnien E (1998) Extremophile microorganisms as cell factories: support from the European Union. Extremophiles 2:367-373

Altschul SF, Gish W, Miller W, Myers EW, Lipman DJ (1990) Basic local alignment search tool. J Mol Biol 215:403-410

Bornemann S, Cassells JM, Dordick JS, Hacking AJ (1992) The use of enzymes to regioselectivity deacylate sucrose esters. Biocatalysis $7: 1-12$

Bornscheuer UT (2002) Microbial carboxyl esterases: classification, properties and application in biocatalysis. FEMS Microbiol Rev 733:1-9

Bradford MM (1976) A rapid and sensitive method for the quantitation of microgram quantities of protein utilizing the principle of protein-dye binding. Anal Biochem 72:248-251

Eggert T, Pencreac'h G, Douchet I, Verger R, Jaeger KE (2000) A novel extracellular esterase from Bacillus subtilis and its conversion to a monoacylglycerol hydrolase. Eur J Biochem 267: 6459-6469

Ewis HE, Abdelal AT, Lu CD (2004) Molecular cloning and characterization of two thermostable carboxyl esterases from Geobacillus stearothermophilus. Gene 329:187-195

Faber K (1997) Biotransformations of non-natural compounds: state of the art and future development. Pure Appl Chem 69:16131633

Guagliardi A, Manco G, Rossi M, Bartolucci S (1989) Stability and activity of thermostable malic enzyme in denaturants and watermiscible organic solvents. Eur J Biochem 7:248-254

Haki GD, Rakshit SK (2003) Development in industrially important thermostable enzymes: a review. Bioresour Technol 89:17-34

Jaeger KE, Dijkstra BW, Reetz MT (1999) Bacterial biocatalysts: molecular biology, three-dimensional structures and biotechnological applications of lipases. Annu Rev Microbiol 53:315-351

Janssen PH, Monk CR, Morgan HW (1994) A thermophilic lipolytic Bacillus sp., and continuous assay of its $p$-nitrophenyl palmitate esterase activity. FEMS Microbiol Lett 120:195-200

Kademi A, Abdelkader NA, Fakhreddine L, Baratti JC (1999) A thermostable esterase activity from newly isolated moderate thermophilic bacterial strains. Enzyme Microb Technol 24:332338

Kim HK, Park SY, Lee JK, Oh TK (1998) Gene cloning and characterization of thermostable lipase from Bacillus stearothermophilus L1. Biosci Biotechnol Biochem 62:66-71

Kneusel RE, Schiltz E, Matern U (1994) Molecular characterization and cloning of an esterase which inactivates the macrolide toxin brefeldin A. J Biol Chem 269:3449-3456

Kristjansson JK (1989) Thermophilic organisms as sources of thermostable enzymes. TIBTECH 7:349-353

Kubilay M, Ateslier ZBB, Basbulbul G, Biyik HH (2006) Characterization of esterase activity in Geobacillus sp. HBB-4. J Basic Microbiol 46:400-409

Laemmli UK (1970) Cleavage of structural proteins during the assembly of the head of bacteriophage T4. Nature 227:680-685 
Margolin AL (1993) Enzymes in the synthesis of chiral drugs. Enzyme Microb Technol 15:266-280

Maugeri TL, Gugliandolo C, Caccamo D, Stackebrandt E (2001) A polyphasic taxonomic study of thermophilic Bacilli from shallow, marine vents. Appl Microbiol 24:572-587

Miller JA, Nagarajan V (2000) The impact of biotechnology on the chemical industry in the 21 st century. Trends Biotechnol 18:190-191

Mnisi SM, Louw ME, Theron J (2005) Cloning and characterization of a carboxylesterase from Bacillus coagulans 81-11. Current Microbiol 50:196-201

Moher P, Rosslein L, Tamm C (1989) Kinetic resolution of racemic $\beta$-epoxy esters with pig esterase. Tetrahedron Lett 3:2513-2516

Montoro-García S, Martínez-Martínez I, Navarro-Fernández J, Takami H, García-Carmona F, Sánchez-Ferrer Á (2009) Characterization of a novel thermostable carboxylesterase from Geobacillus kaustophilus HTA426 shows the existence of a new carboxylesterase family. J Bacteriol 191:3076-3085

Ollis DL, Cheah E, Cygler M, Dijkstra B, Frolow F, Franken SM et al (1992) The alpha/beta hydrolase fold. Protein Eng 5:197-211

Owsu RK, Cowan DA (1989) Correlation between microbial protein thermostability and resistance to denaturation in aqueous: organic solvent two-phase systems. Enzyme Microb Technol 11:568-574

Owsu RK, Cowan DA (1991) Isolation and partial characterization of a novel thermostable carboxylesterase from a thermophilic Bacillus. Enzyme Microb Technol 3:158-163

Pleiss J, Fischer M, Peiker M, Thiele C, Schmid RD (2000) Lipase Engineering Database: understanding and exploiting sequence- structure-function relationships. J Mol Biocatal B: Enzyme 10:491-508

Quax WJ, Broekhuizen CP (1994) Development of a new Bacillus carboxyl esterase for use in the resolution of chiral drugs. Appl Microbiol Biotechnol 41:425-431

Rua ML, Schmidt-Dannert C, Wahl S, Sprauer A, Schmid RD (1997) Thermoalkalophilic lipase of Bacillus thermocatenulatus largescale production, purification and properties: aggregation behaviour and its effect on activity. J Biotechnol 56:89-102

Schmidt-Dannert C, Rua ML, Atomi H, Schmid RD (1996) Thermoalkalophilic lipase of Bacillus thermocatenulatus PartI. Molecular cloning, nucleotide sequence, purification and some properties. Biochim Biophys Acta 1301:105-114

Soliman NA, Knollb M, Abdel-Fattaha YR, Schmidb RD, Langeb S (2007) Molecular cloning and characterization of thermostable esterase and lipase from Geobacillus thermoleovorans YN isolated from desert soil in Egypt. Process Biochem 42:10901100

Yavuz E, Gunes H, Harsa S, Yenidunya AF (2004) Identification of extracellular enzyme producing thermophilic Bacilli from Balcova (Agamemnon) Geothermal Site by ITS rDNA RFLP. J Appl Microbiol 97:810-817

Yildirim M, Colak A, Col M, Canakci S (2009) A new recombinant phosphotriesterase homology protein from Geobacillus caldoxylosilyticus TK4: an extremely thermo- and $\mathrm{pH}$-stable esterase. Process Biochem 44:1366-1373

Zaks A, Klibanov AM (1998) Enzymatic catalysis in nonaqueous solvents. J Biol Chem 263:3194-3201 